This emphasises the differences between racial groups that are commonly found and is probably explained by iron deficiency.

A further study was undertaken in 116 children aged 6 months to 5 years who were examined in routine community immunisation clinic. Capillary blood samples were taken and analysed both with a portable haemoglobinometer (HemoCue, Clandon Scientific, Aldershot) and with a Coulter counter. Of the 48 children found to be anaemic from Coulter counter measurements, $65 \%$ had a mean corpuscular volume $<70 \mathrm{fl}$ and $88 \%$ a mean volume $<75 \mathrm{fl} ; \mathbf{9 0 \%}$ had a mean corpuscular haemoglobin concentration $<26 \mathrm{pg}$. The haemoglobinometer correctly identified $77 \%$ of anaemic children and $91 \%$ of those who were not anaemic. Of those classified as anaemic by the haemoglobinometer, $69 \%$ had a mean corpuscular volume $<70 \mathrm{fl}$ and $83 \%$ a mean volume $<75 \mathrm{fl} ; 81 \%$ had a mean corpuscular haemoglobin concentration $<26 \mathrm{pg}$. Thus those found to be anaemic by the haemoglobinometer were just as likely to have abnormal variables as those detected by the Coulter counter when capillary blood samples were used. Venous samples seemed to be no better than capillary samples at identifying subjects with abnormal red cell variables.

Haemoglobin concentration and red cell variables are not reliable means of identifying iron deficiency anaemia, but they are simple and can be easily measured in a community clinic. Any programme to screen children for iron deficiency anaemia must, however, also pay close attention to the dietary causes of iron deficiency. Promoting knowledge concerning good weaning practices and actively seeking out children who are given large quantities of fresh cows' milk and starchy solids are as important as measuring blood variables.

ANDREW MILLS

Community and Continuing Care Unit,

slington Health Authority,

London WCIX 0JB

1 Summers A, Elton P, Evans DIK. Iron deficiency in adolescents $\operatorname{BrMed}$ f 1989;298:1521. (3 June.)

\section{A tale of two sisters}

SIR, - Anaesthetists have been blamed for many things. Now its seems that we are responsible for the length of waiting lists for cataract extractions.

In our hospital patients for cataract extraction may have their operation under local or genera anaesthesia, after discussion among the patient, the surgeon, and the anaesthetist and taking into account the physical state of the patient. I can assure Mr Norman Brown that the operating time is exactly the same whichever anaesthetic is used Patients receiving general anaesthesia do indeed spend more time in the recovery area, but this does not delay operations. There are numerous reasons for long waiting lists, but this is certainly not one of them.

JANET E GOOLD

Queen Elizabeth II Hospital,

Hertfordshire AL7 4HQ

1 Brown N. A tale of two sisters. Br Med $\mathcal{J}$ 1989;298:1710. (2 June.

\section{Law lords' decision on consent}

SIR,-Although the recent judgment on consent to medical treatment by mentally handicapped adults' is a positive step towards better standards of medical treatment for handicapped people, many questions remain unanswered.
In regard to sterilisation of handicapped people it is puzzling that only sterilisation in women has come under scrutiny. As the women concerned in recent medicolegal cases have been deemed unable to give their consent would it not then be reasonable to identify and interview their partners to see if they were willing and intellectually able to consent to vasectomy? Clear identification of a woman's partner would not only allow this medically safer alternative to be considered but would also reduce the risk of sterilising a defenceless woman only to facilitate her abuse or exploitation (for example, by carers, relatives, or other clients in her residential establishment). There are good precedents for using male sterilisation when mentally handicapped people are in a consenting relationship.

Recent legislation does not deal with the problem of consent to abortion when a mentally handicapped woman becomes pregnant. As such a pregnancy may very well not be diagnosed until fairly late, there is a need for a legal ruling that permits termination of pregnancy with the minimum delay when indicated.

A recent booklet issued by the Law Society ${ }^{3}$ invites comments from interested people so that steps can be taken to improve the medicolegal situation of handicapped people. It is to be hoped that there is an adequate response from the medical profession to this document.

C D JOLLY

Salford M7 9RN

1 Dyer C. Law lords give reasons for their decision on consent. $B$ Med F 1989;298: 1542. (10 June.)

2 Craft M, Craft A. Sex and the mentally handicapped. London Routledge and Kegan Paul, 1982.

3 Mental Health Subcommitree. Decision making and mental incapacity: a discussion document. London: Law Society, 1989.

\section{Junior doctors and self governing hospitals}

SIR,-Self governing hospital trusts will be allowed to negotiate terms and conditions of service outside the Whitley Council guidelines. Much has been said of how this may benefit the consultants working in these hospitals. The university and postgraduate teaching hospitals that have expressed an interest in self government also employ many junior doctors undergoing higher specialist training. These doctors provide a large part of the service commitment and the posts they fill are strongly contested because they are recognised as a vital step in a successful career.

Currently, junior doctors can follow their chosen career, within their capabilities, without unfair financial hardship because the Whitley Council's terms and conditions of service provide equal pay and conditions dependent on degree of training and responsibility, regardless of the specialty. Once "marketplace economy" is allowed to influence the employment of doctors this freedom of choice and movement will be lost. The management of teaching hospitals with self governing status will be free to offer lower salaries, confident that the career importance of the post will ensure continued strong competition. Furthermore, the free movement of doctors about the country will be curtailed because of the savings made by nonpayment of removal expenses. It may be said that all junior doctors will be in the same boat and free to choose between hospitals managed by district health authorities and self governing hospitals. This is not so; it would be easier for a doctor with no family commitments to accommodate a lower income than one with a partner and children.

If the NHS review is to have the support of junior doctors there must be a commitment from the government that self governing hospitals will continue to abide by the terms and conditions of service for junior doctors defined by the Whitley
Council and the salaries recommended by the Doctors' and Dentists' Review Body.

P J DAWES

Ear, Nose, and Throat Department, Southmead Hospital, Bristol BS10 5NB

\section{Fine print on referrals}

SIR, - I envy Mr John Warden his trust in government platitudes.' Unfortunately, I can see no reason to share his optimism.

Only recently ( 7 June) Kenneth Clarke announced on national radio that most hospital doctors are in favour of the white paper proposals. The figures contradict this statement.

$\mathrm{Mr}$ Warden reassured us that if a self governing hospital goes bust the Secretary of State said that he would have the power to bring it back under district health authority administration. Kenneth Clarke has never promised that the government will do this; in fact he has explicitly stated elsewhere that such hospitals will be allowed to go bankrupt if they cannot successfully compete.

Mr Warden points out Mr Roger Freeman's talk of the importance of clinical freedom, but $\mathrm{Mr}$ Freeman's expectation of the ways contracts will work and his "pledge" referred to by $\mathrm{Mr}$ Warden (last paragraph) commit the government to nothing.

If we seriously want the NHS to remain intact, according to its founding principles, we must read the true fine print of the government's plans and act accordingly, not simply accept unsubstantiated verbal remarks.

Dryburn Hospital, Durham

E JANE RALLS

1 Warden J. Fine print on referrals. Br Med f 1989;298:1545. 10 June.)

\section{Sudden infant death syndrome and the media}

SIR, - I am appalled at the high handed attitude which led to your decision not to publish Mr Barry Richardson's paper linking the sudden infant death syndrome and PVC mattresses, because he had misguidedly leaked the results to the BBC. The publicity increases rather than lessens the need to see the paper for myself. I can well understand your anger with $\mathrm{Mr}$ Richardson, but to take that out on your readers is unfair. A great deal of concern has been aroused by his claims. Jane Smith described how we are deprived of the proper scientific scrutiny and debate about the facts. ${ }^{1}$ As a doctor and as a mother, I do not want to take your word for it that his findings were "no more than a hypothesis." If that were the case a counterargument could easily have been printed alongside his article, to let me decide.

CHRISTINA ROUTH

Upton, Wirral L49 0TD

Smith J. Sudden infant death syndrome and the media. $\mathrm{Br}$ Med $\mathcal{f}$ 1989;298:1601-2. (17 June.)

**We take seriously the task of assessing papers and state clearly the conditions under which we do so: one of these is that authors should not leak their findings to the media (a criterion we share with several other major scientific journals). If they choose to do so they, and not the $B M \mathcal{A}$, deprive readers of the full story. Moreover, although $\mathrm{Dr}$ Routh may not like taking our word for it, there is little other option. In rejecting $80 \%$ of the articles we receive we are inevitably making a judgment, and that is why we take the job of assessing thēse articles seriously. The alternative - of printing everything we receive (with or without counterarguments)-would not, we believe, serve our readers' interests. $-\mathrm{ED}, B M \mathcal{F}$. 